\title{
Morphometric responses and tolerance of pomegranate seedlings irrigated with saline water
}

\author{
João P. N. de Almeida ${ }^{1}$, Vander Mendonça ${ }^{2}$, Anderson A. Alves ${ }^{1}$, Raulino Cardoso Neto ${ }^{1}$, \\ Luilson P. $\operatorname{Costa}^{3} \&$ Francisco S. O. Silva ${ }^{1}$ \\ ${ }^{1}$ Universidade Federal Rural do Semi-Árido/Centro de Ciências Agrárias/Programa de Pós-Graduação em Fitotecnia. Mossoró, RN, Brasil. E-mail: \\ joaopaulonobre@yahoo.com.br (Corresponding author) - ORCID: 0000-0002-7020-993X; anderson270227@hotmail.com - ORCID: 0000-0002-7151- \\ 897X; raulinocardoso@gmail.com- ORCID: 0000-0003-4754-8949; f_sidene@hotmail.com - ORCID: 0000-0001-8488-025X \\ ${ }^{2}$ Universidade Federal Rural do Semi-Árido/Centro de Ciências Agrárias/Departamento de Ciências Agronômicas e Florestais. Mossoró, RN, Brasil. \\ E-mail: vander@ufersa.edu.br - ORCID: 0000-0001-5682-5341 \\ ${ }^{3}$ Universidade Federal do Ceará/Centro de Ciências Agrárias/Programa de Pós-Graduação em Agronomia/Fitotecnia. Fortaleza, CE, Brasil. E-mail: \\ luilson.costa@yahoo.com.br - ORCID: 0000-0002-6758-0180
}

\begin{abstract}
Information on the production of seedlings and initial growth of pomegranate irrigated with saline water is scarce in the Brazilian semi-arid region. The objective of this study was to assess the effect of irrigation water salinity levels on the growth and tolerance of pomegranate seedlings. The experiment was conducted in a greenhouse, located at the Federal Rural University of the Semi-Arid Region, Mossoró, $\mathrm{RN}$, Brazil. A randomized block design with five treatments [electrical conductivities of irrigation water $(\mathrm{ECw})$ of $0.6,3.0,6.0,9.0,12.0 \mathrm{dS} \mathrm{m} \mathrm{m}^{-1}$ ] and five replicates, with three plants per plot, was used. At 120 days after sowing, the following characteristics were evaluated: shoot, root and total lengths $(\mathrm{cm})$; stem diameter $(\mathrm{mm})$, dry mass of stem, leaves, root system and total $(\mathrm{g})$; ratio between root and shoot dry mass; Dickson quality index and salinity tolerance. Growth and dry biomass accumulation in pomegranate seedlings were compromised with increased salinity in irrigation water, but with a lower intensity when subjected up to EC of $6.0 \mathrm{dS} \mathrm{m}^{-1}$. Regarding the criterion of evaluation of tolerance to salinity, pomegranate seedlings were moderately tolerant to salinity.
\end{abstract}

Key words: Punica granatum L., salinity, propagation

\section{Respostas morfométricas e tolerância de mudas de romãzeira irrigadas com água salina}

RESUMO: As informações sobre a formação de mudas e crescimento inicial da romãzeira irrigada com água salina são escassas nas condições do semiárido brasileiro. Com isso, objetivou-se estudar o efeito dos níveis de salinidade da água de irrigação sobre o crescimento e a tolerância de mudas de romãzeiras. O experimento foi conduzido em casa de vegetação, localizado na Universidade Federal Rural do Semiárido, Mossoró/RN. Utilizou-se o delineamento em blocos casualizados com cinco tratamentos [condutividades elétricas da água de irrigação (CEa) de 0,$6 ; 3,0 ; 6,0 ; 9,0 ; 12,0 \mathrm{dS} \mathrm{m}^{-1}$ ] e cinco repetições, com três plantas por parcela. Aos 120 dias após a semeadura foram avaliadas as características: comprimento da parte aérea, radicular e total $(\mathrm{cm})$; diâmetro do caule $(\mathrm{mm})$, massa seca do caule, da folha, do sistema radicular e total (g); razão massa seca da raiz e parte aérea; índice de qualidade de Dickson e tolerância à salinidade. O crescimento e o acúmulo de biomassa seca em mudas de romãzeiras foram comprometidos com o aumento da salinidade na água de irrigação, porém com menor intensidade quando submetida até CEa de 6,0 dS m ${ }^{-1}$ Quanto ao critério de avaliação de tolerância à salinidade, as mudas de romãzeiras se apresentaram moderadamente tolerante à salinidade.

Palavras-chave: Punica granatum L., salinidade, propagação 


\section{INTRODUCTION}

Pomegranate has aroused the interest of several fruit growers, mainly in the Northeast region of Brazil, because this species, previously cultivated in small areas, has evolved to large production areas. In Spain, 'Mollar de Elche' pomegranate is the most popular and most cultivated due to its vigorous characteristics, fast growth and adaptation to semi-arid climate conditions (MARM, 2010).

From the agricultural point of view, it is a species with potential for the market and, in order to meet new demands, it is necessary to know its mechanisms of adaptation to adverse conditions and produce quality seedlings adapted to the semi-arid conditions of Brazil. The factors that most limit the development of species in arid environments is water scarcity and salinity.

The study on the tolerance of the crop to salinity is important because it generates knowledge about its cultivation in saline environments as well as understanding on the mechanisms used by the plant to withstand such stress condition (Bhatt et al., 2008). Thus, using saline water in the irrigation of pomegranate seedlings can be a promising alternative because it is a species with characteristics of survival in semi-arid environment. The utilization of saline waters for irrigation with technical viability has increased water availability for agricultural production (Ribeiro et al., 2016).

Salinity is one of the most important limiting factors among abiotic stresses, which restricts plant growth, affecting its physiology and biochemistry (Khan \& Panda, 2008). Reductions of development and growth in some fruit crops caused by the use of saline water have already been observed by several researchers (Cavalcante et al., 2010; Fernandes et al., 2011; Sá et al., 2013).

In this context, information on the production of seedlings and initial growth of pomegranate irrigated with saline water is scarce. Thus, this study aimed to assess the effect of levels of irrigation water salinity on the growth and tolerance of pomegranate seedlings.

\section{Material ANd Methods}

The experiment was conducted in the period from September 2016 to January 2017 in a greenhouse at the Center of Agrarian Sciences of the Federal Rural University of the Semi-Arid Region (UFERSA), in the municipality of Mossoró-
$\mathrm{RN}$, Brazil, located at geographic coordinates $5^{\circ} 11^{\prime} \mathrm{S}, 37^{\circ} 20^{\prime}$ $\mathrm{W}$, at $18 \mathrm{~m}$ of altitude, with mean annual temperature around $27.50{ }^{\circ} \mathrm{C}$, relative humidity of $68.9 \%$ and mean annual rainfall of $673.9 \mathrm{~mm}$, with hot and dry climate, located in the semi-arid region of Northeast Brazil (Carmo Filho et al., 1991).

The experiment was conducted using seeds of pomegranate (cv. Mollar) collected from ripe fruits obtained at a farm in the municipality of Governador Dix-Sept Rosado-RN, coming from the same lot and at full maturity. After obtaining the fruits, they were sent to the Laboratory of Seed Analysis of the Plant Science Department of UFERSA, where the seeds were extracted and manually processed using a $\# 1 / 4-$ mesh sieve to remove the sarcotesta and then soaked in distilled water at ambient temperature for $96 \mathrm{~h}$ to accelerate and uniformize germination.

Initially, pomegranate seeds were sown on polystyrene trays with 128 cells, filled with commercial substrate based on coconut fiber, by placing one seed per cell. After sowing, at 30 days, seedlings were transplanted to Citropote tubes (3.8 L volume) containing as substrate a mixture of soil (75\%) collected at the UFERSA campus and well decomposed manure ( $25 \%$ of its volume), whose chemical analysis was conducted at the laboratory of UFERSA (Table 1).

Treatments were distributed in a randomized complete block design, which consisted of five treatments and five replicates, with three plants per plot. Treatments corresponded to five levels of irrigation water salinity, in which the control treatment $\left(0.6 \mathrm{dS} \mathrm{m}^{-1}\right)$ was prepared using water from the local supply and the others were obtained by dissolving $\mathrm{NaCl}$ in supply water (EC of 3.0, 6.0, 9.0, $12.0 \mathrm{dS} \mathrm{m}^{-1}$ ). The levels of electrical conductivity of the solutions were obtained using the equation of Richards (1954) and checked with a digital conductivity meter (Tec-4MP), properly calibrated. The results of the analysis of each water can be found in Table 2 and the results of the chemical analysis of each substrate at the end of the experiment are presented in Table 3.

Saline treatments began to be applied at 10 days after transplanting, and irrigations were carried out daily in the late afternoon and based on the volume required to maintain the soil close to field capacity, according to each treatment. Every seven days, an irrigation depth was applied along with a leaching fraction of 0.20 .

At 120 days after sowing, the following characteristics were evaluated: shoot, root and total lengths $(\mathrm{cm})$; stem diameter $(\mathrm{mm})$; dry masses of stem, leaves, root system and total $(\mathrm{g})$;

Table 1. Chemical analysis of the substrate used to produce pomegranate seedlings

\begin{tabular}{|c|c|c|c|c|c|c|c|c|c|c|c|}
\hline \multirow{2}{*}{ Substrate } & $\mathrm{Ca}^{2+}$ & $\mathrm{Mg}^{2+}$ & $\mathrm{A}^{3+}$ & $\mathrm{Al}+\mathrm{H}$ & $\mathbf{N}$ & $\mathbf{P}$ & $\mathbf{K}^{+}$ & $\mathrm{Na}^{+}$ & OM & \multirow{2}{*}{$\stackrel{\mathrm{pH}}{\mathrm{H}_{2} \mathrm{O}}$} & \multirow{3}{*}{$\begin{array}{c}\text { ECse } \\
\text { (dS dm-1) } \\
0.120\end{array}$} \\
\hline & \multicolumn{4}{|c|}{$\left(\mathrm{cmol}_{\mathrm{c}} \mathrm{dm}^{-3}\right)$} & \multicolumn{3}{|c|}{$\left(\mathrm{mg} \mathrm{dm} \mathrm{m}^{-3}\right)$} & & & & \\
\hline Soil +1 & 2.26 & 1.2 & 0 & 1.44 & 0.84 & 5.79 & 3.70 & 11.23 & 8.10 & 6.3 & \\
\hline
\end{tabular}

Source: Laboratory of Soil Fertility of UFERSA; ECse - Electrical conductivity of the saturation extract

Table 2. Analysis of the water from the treatments used in the irrigation of pomegranate seedlings

\begin{tabular}{|c|c|c|c|c|c|c|c|c|c|c|c|c|}
\hline \multirow{2}{*}{$\begin{array}{l}\text { Treatments } \\
\text { (dS } \mathrm{m}^{-1} \text { ) }\end{array}$} & \multirow{2}{*}{$\begin{array}{c}\mathrm{pH} \\
\text { (water) }\end{array}$} & $\mathrm{K}^{+}$ & $\mathrm{Na}^{+}$ & $\mathrm{Ca}^{2+}$ & $\mathrm{Mg}^{2+}$ & $\mathrm{Cl}^{-}$ & $\mathrm{CO}_{3}{ }^{2-}$ & $\mathrm{HCO}_{3}^{-}$ & \multirow{2}{*}{$\begin{array}{l}\text { Hardness } \\
\left(\mathrm{mg} \mathrm{L}^{-1}\right)\end{array}$} & \multirow{2}{*}{ SAR } & \multirow{2}{*}{\multicolumn{2}{|c|}{$\frac{\text { Cations } \quad \text { Anions }}{\left(\mathrm{mmol}_{\mathrm{C}} \mathrm{L}^{-1}\right)}$}} \\
\hline & & \multicolumn{7}{|c|}{$\left(\mathrm{mmol}_{\mathrm{c}} \mathrm{L}^{-1}\right)$} & & & & \\
\hline 0.6 & 6.8 & 0.28 & 5.09 & 0.8 & 0.3 & 2.0 & 0.4 & 3.7 & 55 & 6.9 & 6.5 & 6.1 \\
\hline 3.0 & 8.0 & 0.29 & 24.85 & 0.9 & 0.3 & 17.8 & 1.2 & 3.6 & 60 & 32.1 & 26.3 & 22.6 \\
\hline 6.0 & 8.1 & 0.63 & 43.08 & 0.9 & 0.3 & 46.2 & 1.0 & 3.3 & 60 & 55.6 & 44.9 & 50.5 \\
\hline 9.0 & 7.4 & 0.67 & 70.42 & 1.1 & 0.8 & 81.6 & 0.2 & 2.2 & 95 & 72.2 & 73.0 & 84.0 \\
\hline 12.0 & 7.7 & 1.13 & 85.17 & 0.8 & 1.0 & 107.2 & 0.2 & 2.2 & 90 & 89.8 & 88.1 & 109.6 \\
\hline
\end{tabular}


Table 3. Chemical analysis of the substrate after the experiment

\begin{tabular}{|c|c|c|c|c|c|c|c|c|c|c|c|c|c|c|}
\hline \multirow{2}{*}{ Treat. } & \multirow{2}{*}{$\begin{array}{l}\mathrm{pH} \\
\mathrm{H}_{2} \mathrm{O}\end{array}$} & \multirow{2}{*}{$\begin{array}{c}E C \\
\left(\mathrm{dS} \mathrm{m}^{-1}\right)\end{array}$} & \multirow{2}{*}{$\begin{array}{c}\mathrm{OM} \\
\left(\mathrm{g} \mathrm{dm}^{-3}\right)\end{array}$} & $\mathbf{P}$ & $\mathbf{K}^{+}$ & $\mathrm{Na}^{+}$ & $\mathrm{Ca}^{2+}$ & $\mathrm{Mg}^{2+}$ & $\mathrm{Al}^{3+}$ & $(\mathrm{H}+\mathrm{Al})$ & SB & \multirow{2}{*}{$\begin{array}{c}\text { CEC } \\
\%\end{array}$} & \multirow{2}{*}{ V } & \multirow{2}{*}{$\begin{array}{c}\text { ESP } \\
\%\end{array}$} \\
\hline & & & & \multicolumn{2}{|c|}{$\mathrm{mg} \mathrm{dm^{-3 }}$} & \multicolumn{6}{|c|}{$\left(\mathrm{cmol}_{\mathrm{c}} \mathrm{dm}^{-3}\right)$} & & & \\
\hline 0.6 & 6.50 & 1.67 & 16.55 & 437.8 & 1.96 & 3.46 & 4.2 & 2.0 & 0 & 1.32 & 11.62 & 12.94 & 90 & 27 \\
\hline 3.0 & 6.40 & 2.09 & 6.62 & 375.3 & 1.43 & 5.23 & 3.2 & 1.5 & 0 & 1.60 & 11.35 & 12.51 & 91 & 42 \\
\hline 6.0 & 7.30 & 1.40 & 23.58 & 237.0 & 0.40 & 4.75 & 2.9 & 0.8 & 0 & 0 & 8.85 & 8.85 & 100 & 54 \\
\hline 9.0 & 7.60 & 1.49 & 5.38 & 263.9 & 0.30 & 5.49 & 2.5 & 0.5 & 0 & 0 & 8.79 & 8.79 & 100 & 62 \\
\hline 12.0 & 7.70 & 1.23 & 7.03 & 766.6 & 0.31 & 7.34 & 2.4 & 0.7 & 0 & 0 & 10.76 & 10.76 & 100 & 68 \\
\hline
\end{tabular}

ratio between root and shoot dry mass; and Dickson quality index (DQI), calculated by the formula: DQI $=[\mathrm{TDM} /(\mathrm{TL} / \mathrm{SD})$ $+($ ShDM/RDM) $]$ (Dickson et al., 1960), where: TDM - total dry mass; TL - total length; SD - stem diameter; ShDM - shoot dry mass and RDM - root dry mass ratio.

Collar diameter was measured using a digital caliper with $0.01 \mathrm{~mm}$ accuracy. Shoot length was measured from the collar to the apical bud, whereas root system length was measured from the collar to the tip of the longest root. Length measurements were taken using a ruler graduated in centimeters.

The dry mass of each segment was determined by placing each part in Kraft paper bags, drying in forced air circulation oven at $60{ }^{\circ} \mathrm{C}$, until reaching constant weight, and then weighing on analytical scale with precision of $0.001 \mathrm{~g}$. Total dry mass was obtained by summing shoot dry mass and root system dry mass.

Pomegranate seedlings were evaluated for their tolerance to salinity based on the measurement of reductions in the expression of total dry biomass production observed at the different levels of salinity, relative to the control, according to the equation suggested by Fageria et al. (2010):

$$
\mathrm{RP}=\left[\frac{(\text { Pcontrol }- \text { Psalinity })}{\text { Pcontrol }}\right] 100
$$

where:

RP - Reduction in total dry biomass production, \%;

Pcontrol - Production of total dry biomass in the treatment without salinity, g plant $^{-1}$; and,

Psalinity - Production of total dry biomass in treatments with salinity, g plant $^{-1}$.

With these values of reduction of production, the results were interpreted based on Table 4, proposed by Fageria et al. (2010).

The obtained data were subjected to Komolgorov test to analyse the normality of distribution. When the data were normal, analysis of variance was carried out and, when significant, they were subjected to polynomial regression analysis ( $\mathrm{p}<0.05)$ using the program ASSISTAT (Silva \& Azevedo, 2009).

Table 4. Classification of tolerance to salinity, based on the reduction of total dry biomass production

\begin{tabular}{|clc|}
\hline $\begin{array}{c}\text { Reduction of total dry } \\
\text { biomass production (\%) }\end{array}$ & \multicolumn{1}{c|}{ Classification } & Abbreviation \\
$0-20$ & Tolerant & T \\
$21-40$ & Moderately tolerant & MT \\
$41-60$ & Moderately susceptible & MS \\
$>60$ & Susceptible & S \\
\hline
\end{tabular}

Source: Fageria et al. (2010)

\section{Results AND Discussion}

There was a significant effect of salinity levels on all growth variables of pomegranate seedlings, except root system length (RSL), which had overall mean of $41.37 \mathrm{~cm}$.

Increased irrigation water salinity linearly reduced shoot length (Figure 1A), total length (Figure 1B) and stem diameter (Figure 1E) in pomegranate seedlings, causing decreases of 25.73, 20 and 23.24\%, respectively, in plants irrigated using water with the highest EC level $\left(12.0 \mathrm{dS} \mathrm{m}^{-1}\right)$, compared to those irrigated with supply water (EC $\left.0.6 \mathrm{dS} \mathrm{m}^{-1}\right)$. Compared to the intermediate level of salinity $\left(6.0 \mathrm{dS} \mathrm{m}^{-1}\right)$, such reduction was less expressive, being equal to $12.2 \%$ for shoot length, $9.4 \%$ for total length and $11.0 \%$ for stem diameter.

Salinity reduces growth and stem diameter in several fruit species and their level of tolerance or sensitivity varies according to the genotype. Water stress, induced by salt concentration, reduces growth not only due to the effects on $\mathrm{CO}_{2}$ assimilation, but also due to the reduction in the rates of cell division and elongation (Freire et al., 2010).

In the papaya crop, for instance, salinity caused linear reduction in the stem diameter and shoot length of the studied seedlings (Silva et al., 2008; Coelho et al., 2015). For the production of dwarf green coconut seedlings, there were linear negative responses of growth and stem diameter as soil salinity increased (Medeiros et al., 2017). Similar results were reported by Souza et al. (2015), who observed that increasing electrical conductivity of irrigation water caused linear decreasing effect on plant height and stem diameter in guava rootstocks.

Excess of salts in the root zone of the plants reduces their growth and development, due to the greater osmotic effect outside the root and restriction to water flux from the soil to the plants, required for survival and production under salt stress conditions (Rhoades et al., 2000).

According to Munns (2002), reduction of growth in plants under salt stress is due to the osmotic effect, associated with the toxicity of ions due to the excessive absorption of sodium and chloride and to the nutritional imbalance caused by disorders in absorption and/or distribution of nutrients. As can be viewed in Table 2, the results of the chemical analysis of the solutions show that at EC of 9.0 and $12.0 \mathrm{dS} \mathrm{m}^{-1}$ presented higher contents of $\mathrm{Na}^{+}$and $\mathrm{Cl}^{-}$, which may have contributed to the reduction in the growth of pomegranate seedlings.

The increase in irrigation water electrical conductivity from 0.6 to $12.0 \mathrm{dS} \mathrm{m}^{-1}$ caused a $42.3 \%$ reduction in stem dry mass (Figure 1F). However, at the intermediate level of salinity $\left(6.0 \mathrm{dS} \mathrm{m}^{-1}\right)$, such decrease was lower $(20.1 \%)$. Similar response was also found for leaf dry mass, presented in Figure 1C, which 

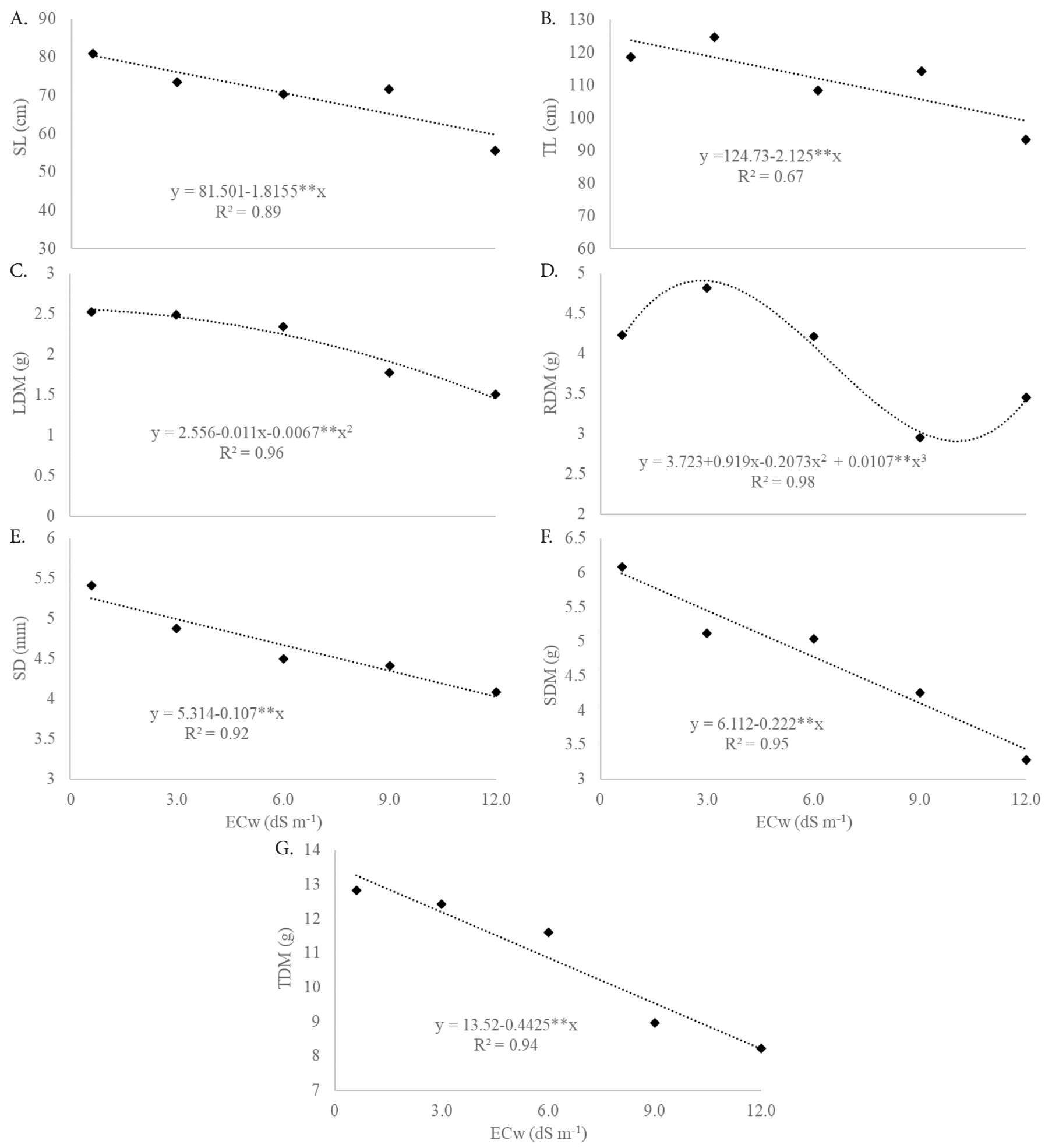

*, ** Significative at 0.05 and 0.01 , respectively, by $\mathrm{F}$ test

Figure 1. Shoot length - SL (A), Total length - TL (B), Leaf dry mass - LDM (C), Root dry mass - RDM (D), Stem diameter - SD (E), Stem dry mass - SDM (F) and Total dry mass - TDM (G) of pomegranate seedlings in function of electrical conductivity of irrigation water $(\mathrm{ECw})$

shows a decrease of $42.75 \%$ between supply water and the highest level of salinity $\left(12.0 \mathrm{dS} \mathrm{m}^{-1}\right)$ and a reduction of $11.76 \%$ at the intermediate level of salinity $\left(6.0 \mathrm{dS} \mathrm{m}^{-1}\right)$.

For the root dry mass of pomegranate seedlings (Figure $1 \mathrm{D})$, the increase in irrigation water electrical conductivity from 0.6 to $3.0 \mathrm{dS} \mathrm{m}^{-1}$ resulted in a $16.7 \%$ increase of biomass and, from this point on, there was a reduction of $30.81 \%$ with the highest level of salinity $\left(12.0 \mathrm{dS} \mathrm{m}^{-1}\right)$. Such increase in dry biomass at EC of $3.0 \mathrm{dS} \mathrm{m}^{-1}$ may be related to the survival strategies of the species, one of which is the investment in more roots to absorb water.

In relation to the total dry mass of pomegranate seedlings (Figure $1 \mathrm{G}$ ), as irrigation water salinity increased, their biomass decreased by $38.04 \%$ with EC of $12.0 \mathrm{dS} \mathrm{m}^{-1}$. Up to intermediate salinity, the reduction was less with only $17.96 \%$. Sodium chloride can negatively affect the synthesis and translocation of hormones from the roots to the shoots, essential for leaf metabolism, which results in loss of dry mass (Taiz \& Zeiger, 2013). Studies 
conducted by Morais et al. (2007) reveal that the increase in $\mathrm{NaCl}$ concentration in irrigation water leads to increment of $\mathrm{Na}^{+}$and $\mathrm{Cl}^{-}$contents in plant tissues, reducing the production of root and shoot dry mass in dwarf cashew seedlings. Such claim can be verified in Table 2, which shows higher contents of $\mathrm{Na}^{+}$and $\mathrm{Cl}^{-}$in the solutions which had the highest values of electrical conductivity.

For the root/shoot dry mass ratio (Figure 2A), there was a more significant increase with the increment of salinity of $12.0 \mathrm{dS} \mathrm{m}^{-1}$, which results in higher rate of reduction in shoot dry mass, compared to the root dry mass, which was less affected by the increase of salinity. Studying different levels of salinity, in five clones of early dwarf cashew, Carneiro et al. (2002) found increment in the root/shoot dry mass ratio with increasing electrical conductivity, and shoot growth was more affected by irrigation water salinity than root system growth. This effect can be interpreted as an adaptation to the salt stress; in order to save water, plants reduce their transpiring surface, since water absorption becomes more difficult, as the osmotic potential of the soil solution becomes more negative (Marinho et al., 2005).

There was a reduction (35.65\%) in the Dickson quality index of pomegranate seedlings as irrigation water salinity increased from 0.6 to $12.0 \mathrm{dS} \mathrm{m} \mathrm{m}^{-1}$ (Figure $2 \mathrm{~B}$ ). For the intermediate level, such reduction of DQI was $16.9 \%$. Similar responses were observed in 'oiticica' (Licania rigida) seedlings, whose Dickson quality index was reduced by salinity (Diniz Neto et al., 2014).

DQI is pointed as a good indicator of seedling quality because it is used to calculate the sturdiness (height/stem diameter) and balance in biomass distribution (ShDM/ RDM), so that the higher the DQI, the better the quality of the

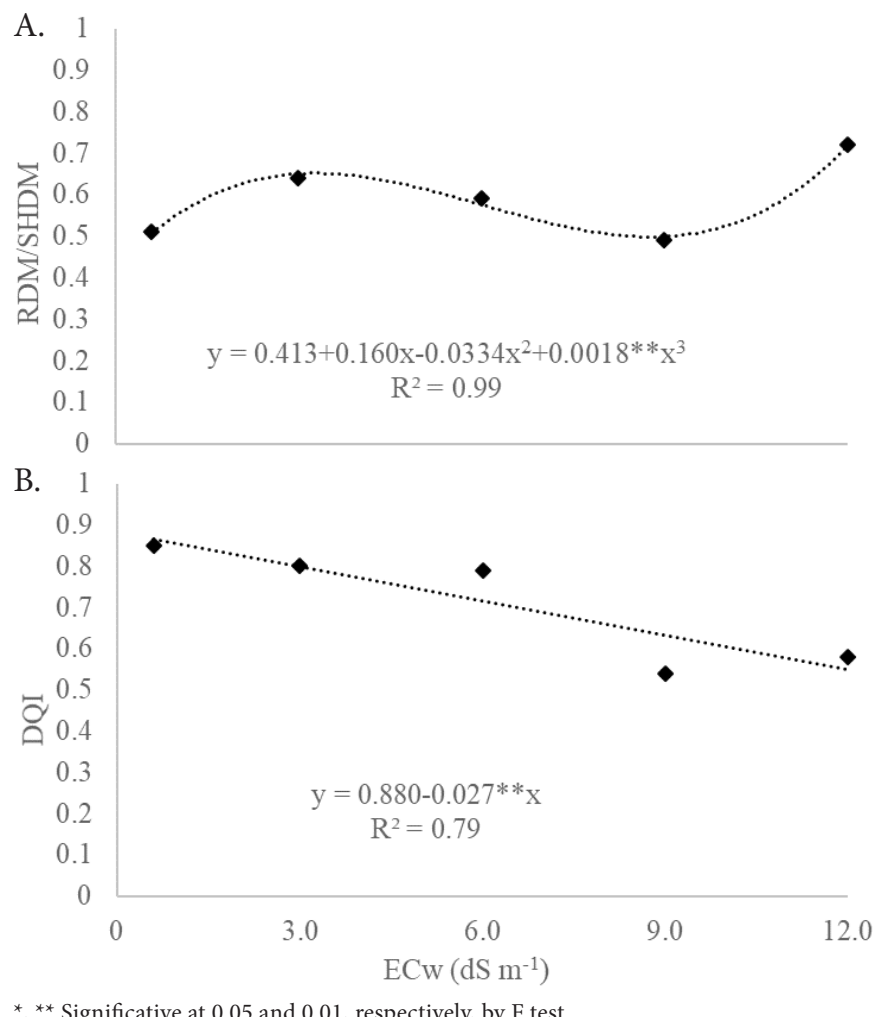

Figure 2. Root/shoot dry mass ratio - RDM/ShDM (A) and Dickson quality index - DQI (B) of pomegranate seedlings irrigated with saline water produced seedling (Cavalcante et al., 2016). According to the criterion of Hunt (1990), DQI values lower than 0.2 indicate seedlings which are not considered as of good quality to be established in the field and the higher the value of DQI, the better the quality of the seedling. In this context, all treatments led to pomegranate seedlings suitable for planting.

Pomegranate seedlings were classified regarding their tolerance to salinity, using the criterion of relative production with the increase in salt stress, considering the total dry phytomass. According to the classification, pomegranate seedlings irrigated using water with salinity levels of 3.0 and $6.0 \mathrm{dS} \mathrm{m}^{-1}$ were tolerant to salinity, with reductions of 8.0 and $17.96 \%$, respectively. On the other hand, under more severe conditions of stress, seedlings irrigated using water with EC of 9.0 and $12.0 \mathrm{dS} \mathrm{m}^{-1}$ were moderately tolerant to salinity, with reductions of 28.04 and $38.04 \%$, respectively.

Similar response was also found by Naeini et al. (2005), who observed that commercial cultivars of pomegranate were moderately tolerant to the stress. Citrus plants are also moderately tolerant to salinity (Nascimento et al., 2015). This result may be related to the fact that pomegranate is highly adaptable to a wide range of climate, water and soil conditions (Holland et al., 2009).

Possibly, this may result from the retention of $\mathrm{Na}^{+}$and $\mathrm{Cl}^{-}$in roots and stems, and these mechanisms are still little studied in plant species, especially in pomegranate. Another factor that may contribute to this level of tolerance of the species is the abscission of old leaves which accumulate considerable amounts of salt (Willadino \& Camara, 2010).

\section{Conclusions}

1. Growth and dry biomass accumulation in pomegranate seedlings were reduced by the increase in irrigation water salinity.

2. In the stage of seedling production, shoot growth is the parameter most affected by salinity.

3. Even though the water salinity influence the Dickon quality index, the pomegranate seedlings remained suitable for planting until electrical conductivity of water $(\mathrm{ECw})$ of $12.0 \mathrm{dS} \mathrm{m}^{-1}$.

4. Regarding the criterion of evaluation of tolerance to salinity, pomegranate seedlings were tolerant to the effects of

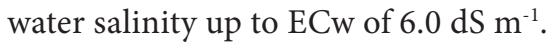

\section{Literature Cited}

Bhatt, M. J.; Patel, A. D.; Bhatti, P. M.; Pandey, A. N. Effect of soil salinity on growth, water status and nutrient accumulation in seedlings of Ziziphus mauritiana (Rhamnacee). Journal of Fruit and Ornamental Plant Research, v.16, p.383-401, 2008.

Carmo Filho F.; Espínola Sobrinho J.; Maia Neto, J. M. Dados climatológicos de Mossoró: Um município semi-árido nordestino. Mossoró: ESAM, 1991. 121p.

Carneiro, P. T.; Fernandes, P. D.; Gheyi, H. R.; Soares, F. A. L. Germinação e crescimento inicial de genótipos de cajueiro anão-precoce em condições de salinidade. Revista Brasileira de Engenharia Agrícola e Ambiental, v.6, p.199-206, 2002. https:// doi.org/10.1590/S1415-43662002000200003 
Cavalcante, A. L. G.; Oliveira, F. de A. de; Pereira, K. T. O.; Dantas, R. de P.; Oliveira, M. K. T. de; Cunha, R. C. da; Souza, M. W. de L. Desenvolvimento de mudas de mulungu fertirrigadas com diferentes soluções nutritivas. Floresta, v.46, p.47-55, 2016. https:// doi.org/10.5380/rf.v46i1.34888

Cavalcante, L. F.; Vieira, M. da S.; Santos, A. F. dos; Oliveira, W. M. de; Nascimento, J. A. M. do. Água salina e esterco bovino líquido na formação de mudas de goiabeira cultivar Paluma. Revista Brasileira de Fruticultura, v.32, p.251-261, 2010. https://doi. org/10.1590/S0100-29452010005000037

Coelho, D. C.; Silva, E. C. B.; Silva, F. M. da; Sousa, E. M. L. de; Nobre, R. G. Crescimento de mudas de mamoeiro em condições controladas com água salina. Revista Verde de Agroecologia e Desenvolvimento Sustentável, v.10, p.1-5, 2015. https://doi. org/10.18378/rvads.v10i1.3218

Dickson, A.; Leaf, A. L.; Hosner, J. F. Quality appraisal of white spruce and white pine seedling stock in nurseries. The Forestry Chronicle, v.36, p.10-13,1960. https://doi.org/10.5558/tfc36010-1

Diniz Neto, M. A.; Silva, I. de F. da; Cavalcante, L. F.; Diniz, B. L. M. T.; Silva, J. C. A. da; Silva, E. C. da. Mudas de oiticica irrigadas com águas salinas no solo com biofertilizante bovino e potássio. Revista Brasileira de Engenharia Agrícola e Ambiental, v.18, p.10-18, 2014. https://doi.org/10.1590/S1415-43662014000100002

Fageria, N. K.; Soares Filho, W. S.; Gheyi, H. R. Melhoramento genético vegetal e seleção de cultivares tolerantes à salinidade. In: Gheyi, H. R.; Dias, N. da S.; Lacerda, C. F. (eds.). Manejo da salinidade na agricultura: Estudos básicos e aplicados. Fortaleza: INCTSal, 2010. Cap.13, p.205-216.

Fernandes, P. D.; Brito, M. E. B.; Gheyi, H. R.; Soares Filho, W. dos S.; Melo, A. S. de; Carneiro, P. T. Crescimento de híbridos e variedades porta-enxerto de citros sob salinidade. Acta Scientiarum. Agronomy, v.33, p.259-267, 2011.

Freire, A. L. de O.; Saraiva, V. P.; Miranda, J. R. P. de; Bruno, G. B. Crescimento, acúmulo de íons e produção de tomateiro irrigado com água salina. Semina: Ciências Agrárias, v.31, p.1133-1144, 2010. https://doi.org/10.5433/1679-0359.2010v31n4Sup1p1133

Holland, D.; Hatib, K.; Bar-Ya’akov, I. Pomegranate: Botany, horticulture, breeding. In: Janick, J. (ed.). Horticultural reviews. New Jersey: John Wiley and Sons, 2009. Chap.2, p.127-191. https:// doi.org/10.1002/9780470593776.ch2

Hunt, G. A. Effect of styroblock design and copper treatment on morphology of conifer seedlings. In: Meeting of the Western Forest Nursery Associations, 1990, Roseburg. Proceedings.... Fort Collins: United States Department of Agriculture Forest Service, 1990. p.218-222.

Khan, M. H.; Panda, S. K. Alterations in root lipid peroxidation and antioxidative responses in two rice cultivars under $\mathrm{NaCl}$-salinity stress. Acta Physiologiae Plantarum, v.30, p.81-89, 2008. https:// doi.org/10.1007/s11738-007-0093-7

Marinho, F. J. L.; Gheyi, H. R.; Fernandes, P. D. Germinação e formação de mudas de coqueiro irrigadas com águas salinas. Revista Brasileira de Engenharia Agrícola e Ambiental, v.9, p.334-340, 2005. https://doi.org/10.1590/S1415-43662005000300007

MARM - Ministerio de Medio Ambiente y Medio Rural y Marino. Anuário de estatística. Madrid: Catálogo General de Publicaciones Oficiales, 2010. 126p.
Medeiros, W. J. F. de; Oliveira, F. I. F. de; Lacerda, C. F. de; Oliveira, D. R. de; Ribeiro, M. da S. de S.; Oliveira, A. da C. Efeitos da salinidade do solo e encharcamento sobre as taxas de crescimento de plantas jovens de coqueiro-anão-verde. Revista Brasileira de Agricultura Irrigada, v.11, p.1315-1323, 2017. https://doi. org/10.7127/rbai.v11n200612

Morais, D. L. de; Viégas, R. A.; Silva, L. M. M.; Lima Junior, A. R.; Costa, R. C. L. da; Rocha, I. M. A.; Silveira, J. A. G. Acumulação de íons e metabolismo de $\mathrm{N}$ em cajueiro anão em meio salino. Revista Brasileira de Engenharia Agrícola e Ambiental, v.11, p.125-133, 2007. https://doi.org/10.1590/S1415-43662007000200001

Munns, R. Comparative physiology of salt and water stress. Plant, Cell and Environment, v.25, p.239-250, 2002. https://doi.org/10.1046/ j.0016-8025.2001.00808.x

Naeini, M. R.; Khoshgoftarmanesh, A. K.; Lessani, H.; Fallahi, E. Effects of sodium chloride-induced salinity on mineral nutrients and soluble sugars in three commercial cultivars of pomegranate. Journal of Plant Nutrition, v.27, p.1319-1326, 2005. https://doi. org/10.1081/PLN-200025832

Nascimento, H. H. C. do; Santos, C. A. dos; Freire, C. S.; Silva, M. A. da; Nogueira, R. J. M. C. Ajustamento osmótico em mudas de jatobá submetidas à salinidade em meio hidropônico. Revista Árvore, v.39, p.641-653, 2015. https://doi.org/10.1590/0100-67622015000400006

Rhoades, J. D.; Kandiah, A.; Mashali, A. M. Uso de águas salinas para produção agrícola. Campina Grande: UFPB, 2000.117p. Irrigation and Drainage Paper, 48

Ribeiro, P. H. P.; Gheyi, H. R.; Uyeda, C. A.; Teixeira, M. B.; Soares, F. A. L.; Dias, N. da S. Taxa de crescimento e produção de girassol irrigado com água salina sob doses de nitrogênio. Irriga, v.edição especial, p.233-247, 2016.

Richards, L. A. Diagnosis and improvement of saline and alkali soils. Washington: United States Department of Agriculture, 1954.160p.

Sá, F. V. da S.; Brito, M. E. B.; Melo, A. S. de; Antônio Neto, P.; Fernandes, P. D.; Ferreira, I. B. Produção de mudas de mamoeiro irrigadas com água salina. Revista Brasileira de Engenharia Agrícola e Ambiental, v.17, p.1047-1054, 2013. https://doi. org/10.1590/S1415-43662013001000004

Silva, F. A. S.; Azevedo, C. A. V. Principal components analysis in the software assistat-statistical assistance. In: World Congress on Computers in Agriculture, 7, 2009, Reno. Proceedings... St. Joseph: ASABE, 2009. CD-Rom.

Silva, S. M. S.; Alves, A. N.; Gheyi, H. R.; Beltrão, N. E. de M.; Severino, L. S.; Soares, F. A. L. Desenvolvimento e produção de duas cultivares de mamoneira sob estresse salino. Revista Brasileira de Engenharia Agrícola e Ambiental, v.12, p.335-342, 2008. https:// doi.org/10.1590/S1415-43662008000400001

Souza, L. de P.; Nobre, R. G.; Silva, E. M. da; Sousa, F. F. de; Silva, I. A. da. Desenvolvimento de porta-enxerto de goiabeira sob irrigação com água salinizadas e doses de nitrogênio. Revista Verde de Agroecologia e Desenvolvimento Sustentável, v.10, p.176-182, 2015. https://doi.org/10.18378/rvads.v10i2.3717

Taiz, L.; Zeiger, E. Fisiologia vegetal. 5.ed. Porto Alegre: Artmed, 2013. 954p.

Willadino, L.; Camara, T. R. Tolerância das plantas à salinidade: Aspectos fisiológicos e bioquímicos. Enciclopédia Biosfera, v.6, p.1-23, 2010. 